\title{
Wage Inequality, Firm Size and Gender: The Case of CANADA
}

\author{
Sadequl Islam \\ Professor, Department of Economics, \\ Laurentian University, Sudbury, Ontario, Canada \\ Mohammad Safavi \\ Ph.D. Candidate, Human Studies, \\ Laurentian University, Sudbury, Ontario, Canada
}

\begin{abstract}
Using data from the Labor Force Survey, February 2006 and 2019 of Canada, we document a decrease in wage inequality for females and males. In 2006 and 2019, wage inequality in small firms is higher than large firms and much of overall wage inequality occurs within groups (firm size and sex) rather than between groups.
\end{abstract}

\section{INTRODUCTION}

Over the last decades, rising inequality has been a defining feature of many countries. The way rising inequality has directly affected most people is through sluggish hourly wage growth in recent decades, despite an expanding and increasingly productive economy. Most of the research in the area of wage inequality has focused on changes in labor demand (due to technological progress) and supply (evolution of the workforce with respect to experience and education), and on changes in labor market institutions.

The scholarly significance of wage inequality is given by the fact that it is likely to be a major driver of income inequality ( Piketty, 2014, Ch.9). Wage inequality in turn is determined by among others by public policy concerning the education system.

Our paper contributes to the literature by exploring not only overall wage inequality but also wage inequality by firm size and by gender in Canada. In this paper, we decompose wage differences between firms, less than 20 employees, 20 to 99 employees, 100 to 500 employees, and more than 500 employees in Canada in 2019 and 2006. We also decompose wage inequality between males and females.

\section{LITERATURE REVIEW}

Katz, Lawrence, F.; Autor, David H. (1999) mention that an analysis of changes in the US wage structure in the 1980s alone suggests little effect of supply factors since groups with rising relative wages have rising relative supplies (the more-educated, older workers, women) indicating demand shifts are the driving force. Islam, S. \& Safavi, M. (2018) show that changes in income inequality in Canada and U.S have not been driven significantly by changes in the labor share. It is likely that income inequality is driven by other forces such as inequality within labour income, technological changes, globalization, and institutional factors governing the labour market. DiNardo, John; Lemieux, Thomas (1997) indicate that much more severe declines in the unionization rate in the United States than in Canada account for two-thirds of the differential growth in wage inequality between the two countries. Autor, David. H.; Katz, Lawrence F.; Kearney, Melissa S. (2008) demonstrate that skill demand shifts have played a central role in reshaping the wage structure, both during the monotone rise of inequality during the 1980s and the polarization of wage growth that followed. Krusell, Per; Ohanian, Lee 
E.; Ríos-Rull, José-Víctor; Violante, Giovanni L. (2000) illustrate that the increase wage inequality results from economic growth driven by new, efficient technologies embodied in capital equipment.

Juhn, Murphy and Pierce (1993) emphasize that much of the increase in wage inequality for men is caused by increased returns to the components of skill other than years of schooling and years of labor market experience. Helpman, Muendler and Redding (2017) show that much of overall wage inequality arises within sector-occupations and for workers with similar observable characteristics; this within component is driven by wage dispersion between firms; and wage dispersion between firms is related to firm employment size and trade participation. Cosic (2018) shows that from 1992 to 2012, wage inequality increased more quickly in the upper half of the wage distribution. Brown, Hamilton and Medoff (1990) find that in the 1980s, large firms in the United States paid significantly higher wages than small firms for the same positions, occupations and observed characteristics of employees. Oaxaca, Ronald. (1973) find a substantial proportion of the male-female wage differential is attributable to the effects of discrimination. Blinder, Alan (1973) explores the relationship between the gender division of labor, occupational choices, and the gender wage gap in Italy. The results were consistent with gender discrimination in wages. Borjas, Freeman, and Katz (1997) conclude that immigration has had a marked adverse impact on the economic status of the least skilled U.S. workers (high school dropouts and those in the bottom 20 percent of the wage distribution).

Brown, Hamilton, and Medoff (1990) show that there are striking differences between large and small employers - that in fact large employers pay higher wages, offer better fringe benefits, and on average offer a more attractive package of working conditions and compensation. Fortin, Nicole M.; Lemieux, Thomas. (1996) find de-unionization and supply and demand shocks were important factors in explaining the rise in wage inequality from 1979 to 1988.

The theory that Idson and Walter (1999) advanced is that employees at larger firms are more productive and hence command higher wages in a competitive labor market. The shape of the firm- size-wage relation depends on technology, worker preferences, and working conditions. It will change over time and across occupations. Rosen, Sherwin. (1982) shows the distributions of reward and firm size are skewed relative to the distribution of abilities.

Increasing the proportion of skilled workers in the economy leads to a reduction in wage inequality via two effects. The first is a price effect. Skilled workers, earning relatively higher wages, become relatively more abundant and, consequently, see their relative wages shrink. The second is a composition effect. A greater proportion of individuals is now in the skilled (highest wage) group, which also contributes to reducing inequality. These two effects combined lead to the prediction that shifts to the right in both demand and supply of skilled workers that would leave price unchanged would result in less wage inequality, Machado and Mata (2005).

Melly (2005) find that changes in residuals account only for about $20 \%$ in the growth of inequality, suggesting that there was only a moderate increase in the price of unmeasured skills.

\section{DATA AND DESCRIPTIVE STATISTICS}

The main source of data for this research is Labor Statistics Division, Statistics Canada. We use Labor Force Survey, February 2006 and February 2019. Table 1 and Table 2 report descriptive statistics; they show summary for variables HRLYEARN (Hourly Earnings) by categories of SEX 
and summary for variables HRLYEARN (Hourly Earnings) by categories of ESTSIZE (Establishment size) for 2006 and 2019.

It is clearly evident from Table 1 that average wages for male are higher than for female. Furthermore, the variance of wages for male is also higher than for female, suggesting that the degree of wage dispersion is higher for male than for female.

It can be observed from Table 2 that the mean and variance of hourly earnings are higher for large firms than for small firms. Several researchers have observed the fact that large firms pay higher wages compared to small firms to workers with similar characteristics ( for example, Cosic, 2018). Several reasons have been suggested in the literature: large firms have advanced technologies, workers in large firms have higher productivity, and large firms pay "efficiency wages."

Table 1: Summary for variables: HRLYEARN (Hourly Earn) by SEX

\begin{tabular}{|c|c|c|c|c|c|c|c|c|}
\hline SEX & \multicolumn{2}{|c|}{ mean } & \multicolumn{2}{|c|}{$\max$} & \multicolumn{2}{|c|}{$\min$} & \multicolumn{2}{|c|}{ p50 } \\
\hline Year & 2019 & 2006 & 2019 & 2006 & 2019 & 2006 & 2019 & 2006 \\
\hline Male & 29.04 & 20.78 & 110.77 & 108.17 & 3 & 2 & 25.4 & 19 \\
\hline Female & 25.15 & 17.18 & 105.13 & 78.46 & 3 & 2.03 & 21.86 & 15 \\
\hline Total & 27.081 & 18.95 & 110.77 & 108.17 & 3 & 2 & 23.63 & 16.83 \\
\hline SEX & \multicolumn{2}{|c|}{ variance } & \multicolumn{2}{|c|}{ sd } & \multicolumn{2}{|c|}{ skewness } & \multicolumn{2}{|c|}{ kurtosis } \\
\hline Year & 2019 & 2006 & 2019 & 2006 & 2019 & 2006 & 2019 & 2006 \\
\hline Male & 208.90 & 115.16 & 14.45 & 10.73 & 1.26 & 1.26 & 5.02 & 5.72 \\
\hline Female & 151.59 & 81.75 & 12.31 & 9.04 & 1.41 & 1.33 & 5.65 & 5.25 \\
\hline Total & 183.75 & 101.43 & 13.55 & 10.07 & 1.36 & 1.33 & 5.41 & 5.75 \\
\hline
\end{tabular}


Table 2: Summary for variables: HRLYEARN by categories of: ESTSIZE (Establishment size)

\begin{tabular}{|c|c|c|c|c|}
\hline ESTSIZE & \multicolumn{2}{|c|}{ mean } & \multicolumn{2}{|c|}{ p50 } \\
\hline Year & 2019 & 2006 & 2019 & 2006 \\
\hline $\begin{array}{c}\text { Less than } \\
20\end{array}$ & 23.11 & 15.75 & 20 & 13.75 \\
\hline 20 to 99 & 26.36 & 18.68 & 23 & 16.51 \\
\hline $\begin{array}{c}100 \text { to } \\
500\end{array}$ & 29.93 & 21.11 & 26.81 & 19.23 \\
\hline $\begin{array}{c}\text { More } \\
\text { than } 500\end{array}$ & 35.03 & 25.20 & 33 & 24 \\
\hline Total & 27.08 & 18.95 & 23.63 & 16.83 \\
\hline ESTSIZE & \multicolumn{2}{|c|}{ variance } & \multicolumn{2}{|c|}{ kurtosis } \\
\hline Year & 2019 & 2006 & 2019 & 2006 \\
\hline $\begin{array}{c}\text { Less than } \\
20\end{array}$ & 130.92 & 72.57 & 7.91 & 7.75 \\
\hline 20 to 99 & 169.24 & 95.69 & 5.23 & 6.00 \\
\hline $\begin{array}{c}100 \text { to } \\
500\end{array}$ & 196.88 & 102.07 & 5.04 & 5.26 \\
\hline $\begin{array}{c}\text { More } \\
\text { than } 500\end{array}$ & 222.92 & 122.18 & 4.30 & 4.86 \\
\hline Total & 183.75 & 101.43 & 5.41 & 5.75 \\
\hline
\end{tabular}

Table $3 \& 4$ show summary for variables HRLYEARN (Hourly Earn) by categories of NAICS_21 (Industry of main job) for 2019 and 2006.

Industries that offer higher average wages in 2019 are utilities, mining, education, professional, finance, and forestry. Industries which pay lower average wages are agriculture, retail trade, and accommodation. Table also shows that in 2019, the degree of dispersion, as measured by the variance is higher in industries such as mining, finance, professional, and education. On the other hand, the variance of wages is relatively lower in agriculture, business, and accommodation. In 2006 also, average wages were lower in agriculture, retail trade, and accommodation and higher in utilities, education, professional, and finance. 
Table 3: Summary for HRLYEARN by categories of: NAICS_21 (Industry of main job) -2019

\begin{tabular}{|c|c|c|c|c|c|c|}
\hline NAICS_21 & Mean & p50 & variance & sd & skewness & kurtosis \\
\hline Agriculture & 19.56 & 17 & 70.53 & 8.39 & 2.81 & 19.50 \\
\hline Forestry and log & 30.43 & 29.5 & 128.8 & 11.34 & 1.17 & 4.62 \\
\hline Fishing, hunting & 23.74 & 20.75 & 150.15 & 12.25 & 1.19 & 3.89 \\
\hline Mining & 40.68 & 38 & 249.51 & 15.79 & .75 & 3.81 \\
\hline Utilities & 40.23 & 40 & 201.31 & 14.18 & .79 & 4.09 \\
\hline Construction & 29.66 & 28 & 127.99 & 11.31 & 1.16 & 5.87 \\
\hline Manufacturing - Du & 27.69 & 25 & 130.54 & 11.42 & 1.42 & 6.08 \\
\hline $\begin{array}{l}\text { Manufacturing - No- } \\
\text { Du }\end{array}$ & 26.35 & 22.5 & 162.90 & 12.76 & 1.58 & 5.94 \\
\hline Wholesale trade & 27.13 & 24.04 & 144.76 & 12.03 & 1.64 & 6.89 \\
\hline Retail trade & 18.60 & 15 & 83.937 & 9.16 & 2.70 & 13.15 \\
\hline Transportation & 26.45 & 24.04 & 135.46 & 11.63 & 1.82 & 8.79 \\
\hline Finance & 31.03 & 27 & 221.13 & 14.87 & 1.48 & 5.89 \\
\hline Real estate & 25.12 & 21.9 & 153.01 & 12.37 & 1.94 & 8.84 \\
\hline Professional & 34.02 & 30.05 & 271.76 & 16.48 & 1.11 & 4.28 \\
\hline Business & 20.51 & 18 & 77.11 & 8.78 & 2.05 & 8.92 \\
\hline Educational & 33.26 & 30.07 & 217.59 & 14.75 & .90 & 4.1 \\
\hline Health care & 27.40 & 24 & 133.73 & 11.56 & 1.1 & 4.9 \\
\hline Information & 24.26 & 20.19 & 151.53 & 12.31 & 1.48 & 5.7 \\
\hline Accommodation & 15.79 & 14 & 33.79 & 5.81 & 4.20 & 35.87 \\
\hline Other services & 22.88 & 20 & 117.49 & 10.83 & 1.83 & 8.19 \\
\hline Public administration & 36.04 & 34.04 & 172.12 & 13.11 & .84 & 4.31 \\
\hline Total & 27.08 & 23.63 & 183.75 & 13.55 & 1.36 & 5.41 \\
\hline
\end{tabular}


Table 4: Summary for HRLYEARN (Hourly by categories of: NAICS_21 (Industry of main job) 2006

\begin{tabular}{|c|c|c|c|c|c|c|}
\hline NAICS_18 & mean & p50 & sd & variance & kurtosis & skewness \\
\hline Agriculture & 12.32 & 11.35 & 5.40 & 29.22 & 13.82 & 2.44 \\
\hline Forestry & 25.23 & 23.5 & 10.70 & 114.65 & 6.03 & 1.29 \\
\hline Utilities & 28.16 & 26.77 & 10.83 & 117.35 & 4.65 & .92 \\
\hline Construction & 20.01 & 18.95 & 7.92 & 62.8 & 5.39 & 1.05 \\
\hline Manufacture - Du & 21.16 & 19.6 & 9.15 & 83.77 & 7.56 & 1.49 \\
\hline Manufacture - No & 19.07 & 17 & 9.16 & 83.97 & 6.33 & 1.42 \\
\hline Wholesale Trade & 19.28 & 16.91 & 9.89 & 97.98 & 10.09 & 1.95 \\
\hline Retail Trade & 12.74 & 10 & 7.14 & 51.11 & 12.13 & 2.53 \\
\hline Transport & 19.21 & 18.65 & 8.05 & 64.92 & 6.68 & 1.33 \\
\hline Finance & 20.24 & 17.95 & 10.24 & 104.87 & 6.11 & 1.48 \\
\hline Professional & 23.55 & 20.51 & 12.27 & 150.59 & 4.52 & 1.22 \\
\hline Management & 13.59 & 11.38 & 6.69 & 44.83 & 15.89 & 2.79 \\
\hline Educational Service & 24.19 & 22.44 & 10.95 & 120.05 & 3.86 & .80 \\
\hline Health Care & 20.04 & 17.97 & 8.67 & 75.31 & 4.45 & 1.0 \\
\hline Information & 18.13 & 16 & 9.94 & 98.91 & 5.87 & 1.38 \\
\hline Accommodation an & 10.44 & 9 & 4.85 & 23.59 & 19.93 & 3.36 \\
\hline Other Services & 16.24 & 14.18 & 9.01 & 81.15 & 12.12 & 2.09 \\
\hline Public Administration & 25.60 & 24.04 & 10.04 & 100.89 & 5.73 & 1.07 \\
\hline Total & 18.95 & 16.83 & 10.07 & 101.43 & 5.76 & 1.33 \\
\hline
\end{tabular}

\section{DECOMPOSITION OF INEQUALITY: METHODOLOGY}

There are two principal questions about the relationship between firm size and wage distribution that we address: First, do large firms pay higher wages? Second, does wage inequality vary across firms?

In this study, we use two methods that are most suitable for addressing the above questions. The rest of this section outlines briefly each method.

Gini index is the most widely cited measure of inequality; it measures the extent to which the distribution within an economy deviates from a perfectly equal distribution. The index is computed as the ratio of the area between the two curves (Lorenz curve and 45-degree line) to the area beneath the 45-degree line.

To decompose changes in wage distribution between 2006 and 2019 within the four categories of firm size (Less than 20 employees, 20 to 99 employees, 100 to 500 employees, more than 500 employees), we use the Generalized Entropy decomposition. The Theil index is a statistic primarily used to measure economic inequality and other economic phenomena. The Theil index $\mathrm{T}$ is the same as redundancy in information theory which is the maximum possible entropy of the data minus the observed entropy. The values of the GE class of measures vary between zero (perfect equality) and infinity (or one, if normalized). A key feature of these measures is that they are fully decomposable, i.e. inequality may be broken down by population groups or income sources or using other dimensions, which can prove useful to 
policy makers. Another key feature is that researchers can choose a parameter $\alpha$ that assigns a weight to distances between incomes in different parts of the income distribution. For lower values of $\alpha$, the measure is more sensitive to changes in the lower tail of the distribution and, for higher values, it is more sensitive to changes that affect the upper tail (Atkinson and Bourguignon, 2015). The most common values for $\alpha$ are 0,1 , and 2 . When $\alpha=0$, the index is called "Theil's L" or the "mean log deviation" measure. When $\alpha=1$, the index is called "Theil's T" index or, more commonly, "Theil index". When $\alpha=2$, the index is called "coefficient of variation". Similar to the Gini coefficient, when income redistribution happens, change in the indices depends on the level of individual incomes involved in the redistribution and the population size (Bellù, 2006).

\section{RESULTS}

In Table 5, we show wage distributions by firm size for 2006 and 2019. We find that wages have been distributed more unequally among workers employed by small firms than among workers employed by large firms. The difference in wage inequality between small and large firms was particularly pronounced in 2006, when the Gini coefficient of wages at firms with less than 20 employees was 0.28 . At the same time, at firms with more than 500 employees, the Gini coefficient was lower by 0.04, at 0.24. Between 2006 and 2019, overall wage inequality decreased, but it declined faster at small firms. Table 5 also shows that in 2006, wage inequality was slightly higher for female than for male. However, in 2019, wage inequality was the same for male and female workers.

Table 5 also shows inequality by industry. It can be observed that several industries have relatively high wage inequality: a) Information, culture, and Recreation; b) Professional, Scientific and technical services; c) Finance, Insurance, real Estate, and Leasing, d) Manufacturing-non-durable. On the other hand, some industries such as a) Accommodation and Food Services and b) Forestry, Fishing, Mining, Oil and Gas have low wage inequality. Table 5 also demonstrates that during 2006-2019, wage inequality has declined somewhat in most industries. 
Table 5: Wage Inequality (Gini) by Gender, Firm size, and Industry

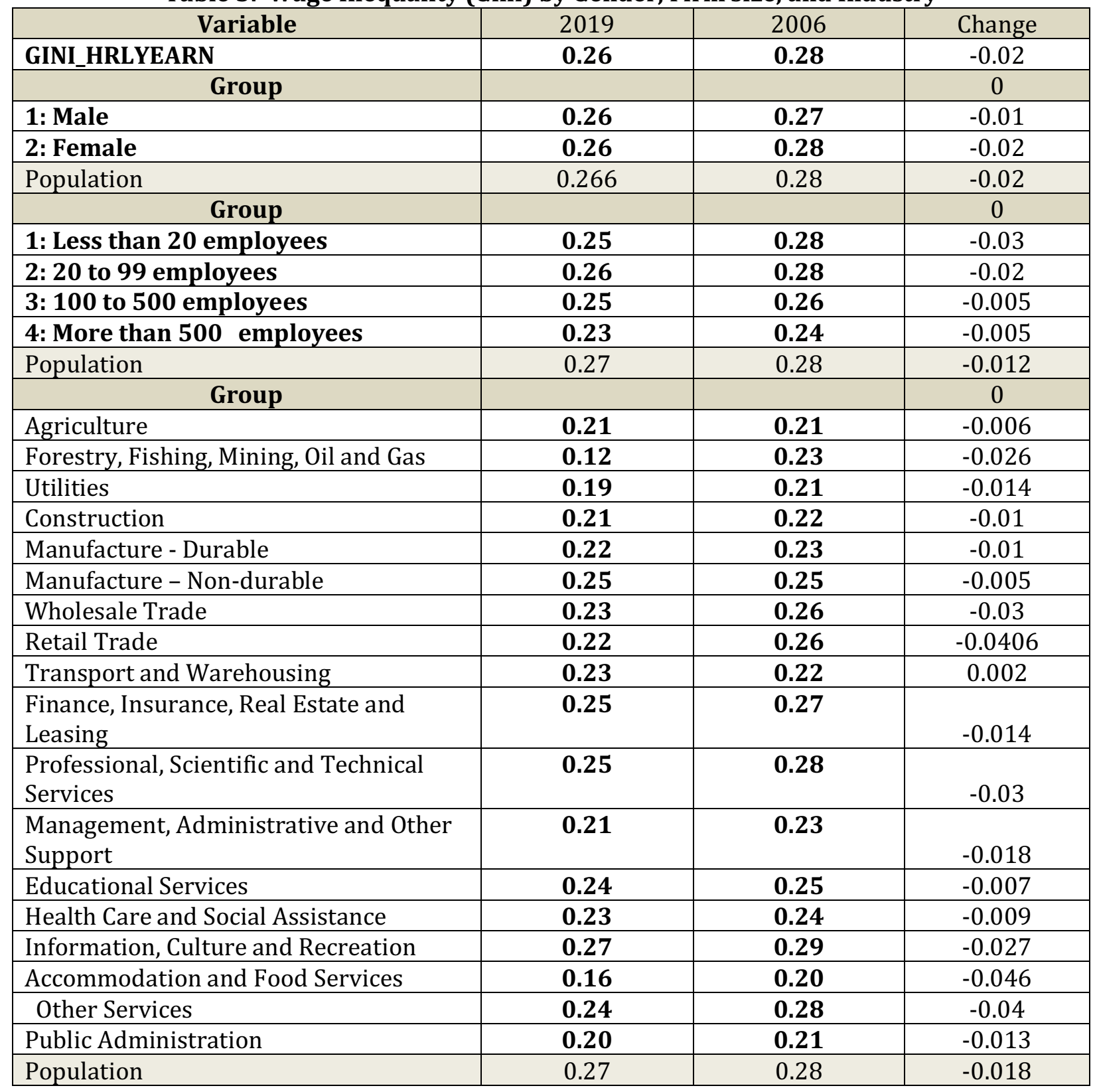

Table 6 reports Percentile ratios - a distributional statistic that, unlike the Gini coefficient, contains information about the shape of a distribution. The 90/10 percentile ratio in 2006 (4.06) was higher than the 90/10 percentile ratio in 2019 (3.31), indicating higher inequality in the bottom of the distribution in 2006.The 90/50 percentile ratio in 2006 (1.93) was at the same level as the $90 / 50$ percentile ratio in 2019 (1.93). Over time, the 75/50 percentile ratio increased by 0.03 per cent (from 1.43 in 2006 to 1.46 in 2019). During 2006-2019, the P10/P50 increased from 0.47 to 0.58 suggesting a decline in wage inequality. Overall, it appears that the relative position of the bottom $10 \%$ in the wage ladder improved compared to the top $10 \%$ and the median group. 
Table 6: Percentile ratios for distribution of HRLYEARN ( All Observations)

\begin{tabular}{|c|c|c|c|c|c|}
\hline \multicolumn{7}{|c|}{2019} \\
\hline $\mathrm{p} 90 / \mathrm{p} 10$ & $\mathrm{p} 90 / \mathrm{p} 50$ & $\mathrm{p} 10 / \mathrm{p} 50$ & $\mathrm{p} 75 / \mathrm{p} 25$ & $\mathrm{p} 75 / \mathrm{p} 50$ & $\mathrm{p} 25 / \mathrm{p} 50$ \\
\hline 3.31 & 1.93 & 0.58 & 2.05 & 1.46 & 0.71 \\
\hline \multicolumn{7}{|c|}{2006} \\
\hline $\mathrm{p} 90 / \mathrm{p} 10$ & $\mathrm{p} 90 / \mathrm{p} 50$ & $\mathrm{p} 10 / \mathrm{p} 50$ & $\mathrm{p} 75 / \mathrm{p} 25$ & $\mathrm{p} 75 / \mathrm{p} 50$ & $\mathrm{p} 25 / \mathrm{p} 50$ \\
\hline 4.06 & 1.93 & 0.47 & 2.19 & 1.43 & 0.65 \\
\hline
\end{tabular}

The results presented so far refer only to changes in the overall wage distribution and do not tell us how these changes break down into changes within groups (defined by firm size and gender) and changes between groups. As tables 7 and 8 illustrate, wage inequality across gender groups has decreased between 2006 and 2019. Wage inequality appears to be slightly higher for male than for female in 2019, as measured by the Gini coefficient. Table 7 and Table 8 clearly show that within-group inequality is much higher than between-- group inequality.

Tables 9 and 10 show wage inequality by firm size and its decomposition. For the less than 20 employees category, we find that Theil index has increased by 0.03 during 2006-2019. Among the more than 500 employees category, the Theil index remained stable. It appears from Tables 9 and 10 that wage inequality has declined for other firm sizes. Three points from tables 9 and 10 are clearly evident: 1) wage inequality, as measured by the Theil Index is higher for small firms than for large firms; 2) within -group inequality dominates the between-group inequality; and 3) within-group inequality has declined during 2006-2019.

Table 7: Generalized Entropy indices GE(a), where a = Wage difference sensitivity parameter, and Gini coefficient (2019)

\begin{tabular}{|l|c|c|c|c|}
\hline \multicolumn{1}{|c|}{ All obs } & $\begin{array}{c}\text { GE(0) } \\
\text { mean log deviation }\end{array}$ & $\begin{array}{c}\text { GE(1) } \\
\text { Theil index }\end{array}$ & $\begin{array}{c}\text { GE(2) } \\
\text { coefficient of variation }\end{array}$ & Gini \\
\hline $\mathbf{2 0 1 9}$ & 0.11 & 0.12 & 0.13 & 0.27 \\
\hline Male & 0.11 & 0.11 & 0.12 & 0.27 \\
\hline Female & 0.10 & 0.11 & 0.12 & 0.26 \\
\hline Within-group inequality & 0.11 & 0.11 & 0.12 & - \\
\hline Between-group inequality & 0.003 & 0.002 & 0.002 & - \\
\hline
\end{tabular}

Table 8: Generalized Entropy indices GE(a), where a = Wage difference sensitivity parameter, and Gini coefficient(2006)

\begin{tabular}{|l|c|c|c|c|}
\hline \multicolumn{1}{|c|}{ All obs } & $\begin{array}{c}\text { GE(0) } \\
\text { mean log deviation }\end{array}$ & $\begin{array}{c}\text { GE(1) } \\
\text { Theil index }\end{array}$ & $\begin{array}{c}\text { GE(2) } \\
\text { coefficient of } \\
\text { variation }\end{array}$ & Gini \\
\hline $\mathbf{2 0 0 6}$ & 0.13 & 0.13 & 0.14 & 0.28 \\
\hline Male & 0.13 & 0.12 & 0.13 & 0.28 \\
\hline Female & 0.12 & 0.12 & 0.14 & 0.28 \\
\hline Within-group inequality & 0.13 & 0.12 & 0.14 & - \\
\hline Between-group inequality & 0.004 & 0.004 & 0.004 & - \\
\hline
\end{tabular}


Table 9: Generalized Entropy indices GE(a), where a = Wage difference sensitivity parameter, and Gini coefficient(2019)

\begin{tabular}{|l|c|c|c|c|}
\hline \multicolumn{1}{|c|}{ All obs } & $\begin{array}{c}\mathrm{GE}(0) \\
\text { mean log deviation }\end{array}$ & $\begin{array}{c}\text { GE }(1) \\
\text { Theil index }\end{array}$ & $\begin{array}{c}\text { GE(2) } \\
\text { coefficient of variation }\end{array}$ & Gini \\
\hline 2019 & 0.11 & 0.11 & 0.12527 & 0.27 \\
\hline Less than 20 employees & 0.09 & 0.16 & 0.12250 & 0.25 \\
\hline 20 to 99 employees & 0.10 & 0.11 & 0.12174 & 0.26 \\
\hline 100 to 500 employees & 0.10 & 0.10 & 0.10987 & 0.25 \\
\hline More than 500 employees & 0.08 & 0.09 & 0.09 & 0.23 \\
\hline Within-group inequality & 0.10 & 0.10 & 0.11 & - \\
\hline Between-group inequality & 0.01 & 0.009 & 0.01 & - \\
\hline
\end{tabular}

Table 10: Generalized Entropy indices GE(a), where a = Wage difference sensitivity parameter, and Gini coefficient(2006)

\begin{tabular}{|l|c|c|c|c|}
\hline \multicolumn{1}{|c|}{ All obs } & $\begin{array}{c}\text { GE(0) } \\
\text { mean log deviation }\end{array}$ & $\begin{array}{c}\text { GE(1) } \\
\text { Theil index }\end{array}$ & $\begin{array}{c}\text { GE(2) } \\
\text { coefficient of variation }\end{array}$ & Gini \\
\hline 2006 & 0.13 & 0.13 & 0.14 & 0.28 \\
\hline Less than 20 employees & 0.12 & 0.13 & 0.15 & 0.28 \\
\hline 20 to 99 employees & 0.13 & 0.12 & 0.14 & 0.28 \\
\hline 100 to 500 employees & 0.10 & 0.11 & 0.11 & 0.26 \\
\hline More than 500 employees & 0.09 & 0.09 & 0.10 & 0.24 \\
\hline Within-group inequality & 0.12 & 0.11 & 0.13 & - \\
\hline Between-group inequality & 0.01 & 0.01 & 0.01 & - \\
\hline
\end{tabular}

\section{CONCLUSION}

In this paper, we decompose wage differences between firms, less than 20 employees, 20 to 99 employees, 100 to 500 employees, and more than 500 employees in Canada in 2019 and 2006. We also decompose wage inequality between males and females.

The results show that large firms pay higher wages than small firms; however, wage inequality in large firms is lower than small firms in 2006 and 2019. The results are consistent with the findings of Cosic ( (2018) for the United States.

Wage inequality in 2019 appears to be lower compared to 2006. This decline can be explained by two factors. First, in this paper we use hourly wage rather than total earnings of workers. It is possible that hourly wage inequality has declined but inequality in total earnings of workers has not. Second, During 2018-2019, most provinces in Canada have significantly raised the minimum wage. This is likely to decrease hourly wage inequality in Canada.

Finally, the findings show that much of overall wage inequality occurs within groups (firm size and sex) rather than between groups.

\section{Reference}

Autor, David. H.; Katz, Lawrence F.; Kearney, Melissa S. 2008. “Trends in US wage inequality: Revising the revisionists", in The Review of Economics and Statistics, Vol. 90, No. 2 (May), pp. 300-323.

Baker, George; Gibbs, Michael; Holmstrom, Bengt. 1994. "The internal economics of the firm: Evidence from personnel data”, in The Quarterly Journal of Economics, Vol. 109, No. 4 (Nov.), pp. 881-919.

Blinder, Alan. 1973. "Wage discrimination: Reduced forms and structural estimates”, in Journal of Human Resources, Vol. 8, No. 4 (Autumn), pp. 436-455.

Borjas, George J.; Freeman, Richard B.; Katz, Lawrence F. 1997. "How much do immigration and trade affect labor market outcomes?", in Brookings Papers on Economic Activity. Vol. 1, pp. 1-90. 
Brown, Charles; Hamilton, James; Medoff, James L. 1990. Employers large and small. Cambridge, Harvard University Press.

Cobb,J.Adam; Ken-Hou Lin. 2017. " Growing apart: The declining firm-size wage premium and its inequality consequences," in Organization Science, 28(3), pp. 429-446.

Cosic, Damir. 2018. "Wage distribution and firm size: The case of the United States", in International Labour Review, Vol. 157, pp. 3

DiNardo, John; Lemieux, Thomas. 1997. “Diverging male wage inequality in the United States and Canada, 19811988: Do institutions explain the difference?”, in Industrial and Labor Relations Review, Vol. 50, No. 4 (July), pp. 629-651.

Fortin, Nicole M.; Lemieux, Thomas. 1996. “Labor market institutions and the distribution of wages, 1973-1992: A semiparametric approach”, in Econometrica, Vol. 64, No. 5 (Sep.), pp. 1001-1044.

Firpo, Sergio; Fortin, Nicole M.; Lemieux, Thomas. 2009. “Unconditional quantile regressions”, in Econometrica, Vol. 77, No. 3 (May), pp. 953-973.

Gabaix, Xavier; Landier, Augustin. 2008. "Why has CEO pay increased so much?", in The Quarterly Journal of Economics, Vol. 123, No. 1 (Feb.), pp. 49-100.

Helpman, E., Itskhoki, O., Muendler, M. and Redding, 2017. "Trade and Inequality: From Theory to Estimation”, Review of Economic Studies Vol. 84, pp. 357-405.

Helpman, E., Itskhoki, O., Muendler, M. and Redding, S. 2012, "Trade and Inequality: From Theory to Estimation”, NBERWorking, pp. 17991.

Idson, Todd L.; Oi, Walter Y. 1999. "Workers are more productive in large firms”, in The American Economic Review, Vol. 89, No. 2 (May), pp. 104-108.

Islam, S., \& Safavi, M. 2018. Income Inequality and Labor Share in U.S.A and Canada. Archives of Business Research, Vol. 6, No. 12, pp. 358-366.

Juhn, Chinhui; Murphy, Kevin M.; Pierce, Brooks. 1993. "Wage inequality and the rise in returns to skill”, in Journal of Political Economy, Vol. 101, No. 3 (June), pp. 410-442.

Katz, Lawrence F.; Autor, David H. 1999. "Changes in the wage structure and earnings inequality”, in Orley C. Ashenfelter and David Card (eds): Handbook of Labor Economics, Vol. 3, Part A. Amsterdam, Elsevier Science B.V., pp. 1463-1555.

Krusell, Per; Ohanian, Lee E.; Ríos-Rull, José-Víctor; Violante, Giovanni L. 2000. “Capital skill complementarity and inequality: A macroeconomic analysis”, in Econometrica, Vol. 68, No. 5 (Sep.), pp. 1029-1053.

Lemieux, Thomas. 2006. "Increasing residual wage inequality: Composition effects, noisy data, or rising demand for skill?", in The American Economic Review, Vol. 96, No. 3 (June), pp. 461-498.

Machado, José A. F.; Mata José. 2005. “Counterfactual decomposition of changes in wage distributions using quantile regression”, in Journal of Applied Econometrics, Vol. 20, No. 4 (Mar.), pp. 445-465.

Melly, Blaise. 2005. "Decomposition of differences in distribution using quantile regression", in Labour Economics, Vol. 12, No. 4 (Aug.), pp. 577-590.

Oaxaca, Ronald. 1973. "Male-female wage differentials in urban labor markets", International Economic Review, Vol. 14, No. 3 (Oct.), pp. 693-709.

Piketty, Thomas,.2014. Capital in the Twenty-First Century. Cambridge: Harvard University Press.

Rosen, Sherwin. 1982. "Authority, control, and the distribution of earnings", in The Bell Journal of Economics, Vol. 13, No. 2 (Autumn), pp. 311-323. 